\title{
Religion and Diaspora: Community Creation in Nineteenth-Century New Zealand, the Case of Antoine Garin and the Catholics of Howick and Nelson
}

\section{GISELLE LARCOMBE}

Antoine Marie Garin was a Catholic missionary who lived in New Zealand from 1841 until 1889. A member of the Society of Mary, the society to which the Pope had given the task of evangelizing Western Oceania in $1835,{ }^{1}$ Garin worked for seven years with Maori in the Bay of Islands and Mangakahia, Northland, before beginning a lengthy career as a parish priest to the settlers of Howick and Nelson. He is best known for his contribution to Catholic education while parish priest of Nelson. ${ }^{2}$

The records kept by Marist missionaries like Garin are fascinating for the way in which they provide an often-overlooked perspective on nineteenthcentury New Zealand. As neither 'colonizing' British settlers, nor 'colonized' Maori, the Marists were in a special position to witness and describe events from their own unique, French viewpoint. Garin's records from his time as parish priest of Howick and Nelson are particularly valuable for their ability to challenge Miles Fairburn's thesis on the atomism of nineteenth-century New Zealand society. As Fairburn notes, nineteenth-century New Zealand migrants had to struggle with atomism: the breaking of ties to family, friends and community that occurred upon migration to such a distant part of the world. With specific reference to religion, Fairburn's thesis paints the nineteenth-century churches as poorly-attended and socially marginal. At a general level, it depicts colonial New Zealand as being gravely deficient in its social organization. ${ }^{3}$ An analysis of Garin's manuscripts, however, shows the extent to which differences of religion, as of ethnicity, could be sources of colonial community.

This paper will consider the community-building that took place within Garin's Catholic parishes in Howick and Nelson through the optics of diaspora studies. While recognizing that today the term 'diaspora' is most readily applied to an ethnic rather than religious minority, it will propose a renewed use of the term in a religious context. The Catholics in New 
Zealand established their own institutions, including schools and orphanages, and Hibernian and Fenian societies, while Catholic publications and popular literature maintained links with the wider Catholic world. In his role as parish priest of Howick and Nelson, Garin worked to establish such Catholic infrastructure and foster Catholic links and communities. He fought for the rights of the Catholic minority in New Zealand, while at the same time adapting to predominantly British, Protestant, late nineteenth-century New Zealand society. ${ }^{4}$

\section{Religion and diaspora in New Zealand}

Diaspora studies as a discipline conceptualizes the dispersions of populations across various geographical locations. It has emerged as a significant area of research, alongside transnationalism, globalization and postcoloniality. The term 'diaspora' is typically used by ethnic groups whose common bond consists in their earlier migration to a foreign place where they establish a separate community. ${ }^{5}$ It was classically used to refer to the dispersal of the Jews, and was adopted subsequently by other groups suffering dispossession, alienation and exile. In recent times the association with collective trauma has lessened so that today the term can be a synonym for a dispersal of people, a community living outside of the homeland, ethnic minorities, and even the act of migration itself. A number of scholars have attempted to define what constitutes a diaspora, including William Safran, James Clifford, Khachig Tölölyan and Robin Cohen, though it appears to be a term that resists precise definition because of the diversity of migration experiences. ${ }^{6}$

Cohen's definition appears the most pertinent to New Zealand studies, as the categories of diaspora he charts include imperial diasporas. Cohen sees diaspora as being formed either by dispersal from an original homeland, corresponding to victim diasporas, or, alternatively, as expansion from a homeland in search of work, to pursue trade, or to further colonial ambitions. ${ }^{\text {? }}$ This second category refers to the ethnic groups that dispersed overseas as part of a colonial project. As Monika Fludernik notes, such groups differ widely from more traditional diasporas in that they belong to the conquering nation and wield great political, military and economic power, as well as dominating the cultural realm. ${ }^{8}$

During his residence in Howick, from 1848 until 1850, Garin worked with predominantly Irish settlers, whose case historically falls within the scope of the diaspora experience. However, the community of Nelson, as a Wakefield settlement town, had a high representation of English settlers, and Garin's small Nelson flock was notable for the presence of an extended family of prosperous English Catholics who were the driving force behind securing a priest for Nelson. As the colonial power and dominant cultural force, English settlers do not traditionally belong to the category of victim 
diasporas, though John Hutnyk sees diaspora theory applying to them, at least for a time. He notes Les Back's description of long-term European migrants in the United States, Canada, South Africa, Australia and New Zealand as the 'white diasporas of the New World'. It was not until the native people were dispersed and the white diasporas became the rightful, albeit controversial owners of the land, that the white diasporas then became 'indigenized' as 'native'. The diasporic trace of white migrants was thus erased, as they came to constitute the model exemplar of the nation state. Hutnyk adds, following Cohen's argument, that investigations into diaspora should not focus solely on 'myths of return' but also allow for the creation of homelands. The British empire could be seen as a kind of diaspora where there was a dispersal of British people around the colonies, people who had some kind of aspiration to return, and an awareness of other dispersed British people..$^{10}$

A major limitation in diaspora studies is the tendency to regard territory as a fundamental base of culture. Diaspora as conceived today does not generally refer to an immigrant grouping based on other aspects of identity, such as religion. Cohen for example sees world religions such as Christianity as 'cognate' phenomena to diasporas, rather than diasporic in themselves. ${ }^{11}$ While not using the term 'diaspora', Jock Phillips and Terry Hearn suggest the possibility of analysing the wider impact of immigrants in New Zealand from the United Kingdom based on religious groupings, which, they say, survived beyond the original national groupings of English, Irish and Scots, whose different customs did not survive far into the second generation. One way of looking at culture in New Zealand at the end of the nineteenth century is to segment society according to four religious/ethnic divisions: the largely southern Irish Catholics; largely English Anglicans; the low-church Protestants who had a strong Scots component mixed with northern Irish Protestants and some English Protestants, especially Methodists; and the 'culturally-mixed blokes of the frontier' comprising the itinerant workers or goldminers, timber-fellers, shepherds and so on. However, the proportion of Catholic Irish settlers in New Zealand was never very high, and the Catholic settlers were in fact a more disparate group than these four divisions suggest. ${ }^{12}$

As an examination of Garin's Nelson congregation demonstrates, Catholicism cut across a number of national boundaries. Garin's congregation was formed by a core of prosperous English Catholics and other disparate nationalities, including Irish, Scots, French, German and Italian. Could one then look at the possibility of the nineteenth-century New Zealand Catholics as a diaspora? As a rule diasporas cross national borders, which should imply precisely that cultural practices are not solely tied to place. 
Cohen outlines nine criteria for a diaspora, some of which must apply for the diaspora to come into existence. ${ }^{13}$ The New Zealand Catholics fall into the category of migrants who have left their homeland in search of work, in pursuit of trade, or to further colonial ambitions. They also exhibit 'a collective memory and myth about the homeland' and 'an idealization of the supposed ancestral home'. According to Fludernik, these features become functional when immigrants group together and establish cultural and religious centres that 're-activate native mythology'. ${ }^{14}$ Garin's parish communities could be said to have re-activated European Catholicism, for example, with their focus on music and ceremony. The criterion of participation in homeland politics was notably present with the New Zealand Catholics, the most obvious example being that of the Irish. They possessed a strong group consciousness sustained over a long time and 'a troubled relationship with the host society'. Nineteenth-century New Zealand was rife with sectarianism, and religious divisions were the site of clashes on a number of national issues, such as the education system. The New Zealand Catholics also sustained 'a sense of solidarity with co-ethnic [co-religious?] members in other countries': ties were strongest with Catholics in Australia but were also maintained with Catholics in Europe and America, thanks to the involvement of Europe-based religious societies in providing clergy and church infrastructure. This sense of solidarity was fostered by a range of Catholic publications distributed worldwide or region-wide, such as Freeman's Journal based in Sydney and the New Zealand Tablet based in Dunedin. Finally, 'the possibility of a distinctive creative, enriching life in tolerant host countries', is also relevant to the New Zealand colonial situation, where opportunities for migrants abounded in comparison to their experiences in Europe. Thus, while to date diaspora terminology has focused on ethnic immigrant groups, the concept appears to have relevance for religious minorities which cut across nationality.

As Malcolm Campbell notes in the preface to an issue of the New Zealand Journal of History on diasporas, the fluid formulation of diasporic identity is critical to understanding the dynamic processes of community establishment (and disestablishment) that occurred within recipient nations. ${ }^{15}$ This is a major difference between migration and diaspora studies, according to Rosalind McClean. Diaspora signals a concern with the transmission and transformation of intergenerational identities and the reasons why, or why not, these identities are realized in community forms. The 'raising of diasporic consciousness' at a community level mimics nation-building, because it depends on a common understanding created through channels of communication, such as letters, books and newspapers that do not necessarily depend on face-to-face contacts, although direct contacts in families, schools, churches and clubs are important too. Diasporas are about perception: 
they are built on a shared belief in commonality. McClean also notes that a shared myth of suffering (or marginalization) can supply the dynamic for politicization, enabling groups to resist those processes of nation-state building that Benedict Anderson describes as the 'erasure' of difference. ${ }^{16}$ An obvious example of this in Garin's case is the establishment of Catholic schools separate from the state system following the Education Act of 1877. Paul Gilroy encapsulated this idea of resistance with his notion of living 'inside, with a difference'. ${ }^{17}$

\section{Garin in Howick, 1848-1850}

In his seminal work on travel, James Clifford describes the set of practices and attitudes that migrants bring to the new country as a 'habitus', a concept which he feels is crucial to discussing diaspora cultures. What, Clifford asks, is brought from a prior place, and how is it maintained and transformed by the new environment? ${ }^{18}$ These questions will be considered here with regards to the Catholic community of Howick, based on the records kept by Garin, their first parish priest.

Howick was established in 1847 in the aftermath of the Northern War, following a request from Governor George Grey for 2500 troops to defend the colony. Of this force, Grey proposed to reserve 1000 men for the occupation of Auckland. The Colonial Office agreed, but insisted that a portion of the troops would be made up of 'a force of a different description', to be designated the Royal New Zealand Fencibles. The Fencibles would consist of approximately 500 men who had been discharged from the British army. The force would be sent directly to Auckland, to be established in two or three villages in the vicinity of the capital prepared for the Fencibles' arrival. Each village was to be provided with a school house which would also serve as a chapel. While they were part of the force, the discharged soldiers would attend military exercises for 12 days each year, and muster under arms at church parade every Sunday, in addition to their military duties if called upon to fight. In return they would be given free passage to New Zealand for themselves and their families, a two-roomed cottage and an acre of land free of rent, and a guarantee of employment for the first year of residence in the colony. Upon the termination of seven years' service, their cottage and allotment would become their own property. ${ }^{19}$

The settlements were eventually placed to the south of Auckland, at Onehunga, Panmure, Otahuhu and Howick, respectively $10 \mathrm{~km}, 14 \mathrm{~km}$, $14 \mathrm{~km}$ and $21 \mathrm{~km}$ from the capital. The distance from the main centre made it difficult for the Fencibles to find private employment. Moreover, the requirement of compulsory attendance at church parade every Sunday severely limited the possibility of gaining work at a distance from the settlements. ${ }^{20}$ Thus, the settlements were necessarily inward-focused, and 
the provision of services within them, including religious services, assumed a certain importance.

A peculiarity of the Fencibles' composition was that most of the men were recruited in Ireland. A total of 2581 immigrants arrived under the Fencibles scheme, comprising 721 military pensioners and their families. ${ }^{21}$ Of the 460 men for whom country of birth was given, nearly $63 \%$ were born in Ireland. This was the most sizeable group of Irish immigrants to arrive in Auckland to date. ${ }^{22}$ It was deemed inappropriate to appoint a single military chaplain, who was likely to have been Anglican, to minister to the entire Fencibles contingent. Instead, Governor Grey arranged for the Anglican and Catholic bishops to provide clergymen. In return for the bishops' cooperation, the government permitted them to select one acre of land in each village for a church and a house for the clergyman. They were also allowed to purchase four acres of land as a glebe, at the price offered to the pensioners. As Grey himself noted, this meant that the Fencible settlements became parishes with their own clergymen, which enhanced the feeling of community in the settlements. ${ }^{23}$

Bishop Philippe Viard, who had been left in charge of the Vicariate of Western Oceania in the absence of Bishop Jean-Baptiste François Pompallier, ${ }^{24}$ assigned Garin to Howick, where the latter arrived on 2 January $1848 .{ }^{25}$ Howick was a large settlement comprising three companies of Fencibles, and was considered to be the chief Fencible settlement at the time. In 1848 it became an administrative centre with a court of petty sessions. ${ }^{26}$ Garin was soon required to minister to Panmure and Otahuhu, which each had one company of Fencibles. Onehunga, another large settlement where three companies were based, was made the responsibility of fellow Marist Antoine Séon.

As Lyndon Fraser notes, one of the most important questions facing Irish scholars today is the degree to which Irish people blended into receiving societies or asserted distinct ethnic identities in their new environment. ${ }^{27}$ In the case of the Irish in New Zealand, this issue is also connected to the character of the Catholic Church, because of the New Zealand Church's non-Irish, French Marist origins. For the first 40 years of their apostolate in New Zealand, French Marist priests outnumbered British priests. Irish migrants found themselves transported to a new land with a foreign priest as the father figure in their community. This was the case for the Fencibles in Howick under the ministry of Garin.

The 'Irish consciousness' which Irish migrants took with them to New Zealand might have led to the rejection of French Marist priests like Garin. ${ }^{28}$ After all, a prominent feature of Irish Catholicism was the close relationship between priest and parishioners: Irish priests at one time risked imprisonment and even death to bring Catholic rites to the people. There 
were indeed signs of division between French priests and Irish parishioners in Howick. In a letter to his brother of 24 August 1848, Garin described his station as consisting of 'old soldiers - Catholics, yes, but old drunkards'. ${ }^{29}$ Drunkenness was a recurrent issue. The Fencible sergeants believed that it was better to have public houses in the Fencible settlements, so that the pensioners would not be encouraged to walk to Auckland for their drinking. When the first four publicans' licences were issued in April 1848 by Captain Charles Henry Montresor Smith, a Fencibles officer and resident magistrate at the court of Howick, they provided one hotel for every 80 adult inhabitants in Howick..$^{30}$ Garin found it difficult to tolerate the presence of these drinking establishments. Upon the death of Catherine Lynch, wife of a local publican, he commented, 'Ever since Owen Lynch has had his public house, things haven't gone well for him; today we had new proof of it'. A brief comment in his diary, that 'The pensioners have started drinking again after St Patrick's Day', and another expressing his satisfaction that only one licence was given for a public house outside of the village in 1850, shows that drinking continued to be a sore point. ${ }^{31}$

Cultural differences were evident in other incidents. In May 1848, two articles appeared in sequential issues of the newspaper New Zealander regarding the loss of a schooner belonging to the Catholic mission, which had been dashed upon the rocks at Howick. The first article was an advertisement placed by Fencible Sergeant William Hawkesworth Barry, asking for subscriptions to replace the vessel. The subscriptions were to be sent to Marist priest Jean Forest, Garin, Hugh Coolahan, ${ }^{32}$ Alexander McDonald or the Fencibles' medical officer, Henry Mahon. The second article, from Forest, stated that neither he nor any of those mentioned in the previous advertisement would be accepting subscriptions. ${ }^{33}$ Here was a potential clash between the Marists' philosophy of remaining 'hidden and unknown', which required that Marists live and work humbly in the Church in order that God's message be heard (a reflection of Mary's role in the apostolic church), and the Irish way of doing things - wholeheartedly, collectively, but also publicly.

These instances of culture clash appear to have been few, however. Garin and the Irish Catholics brought to New Zealand the shared experience of persecution on the grounds of faith, for Garin's parents had endured a period of state-enforced dechristianization during the French Revolution. Garin's formative years were lived during a time when Catholicism and mission were being regrouped in France. In Howick, he sought to maintain the strong, outward faith that both he and his Irish parishioners had known in Europe. He understood, for example, the importance of creating a parish infrastructure. Immediately upon his arrival in Howick, Garin, like fellow Marist Antoine Séon in Onehunga, opened a subscription list for his school 
room, which would act as a temporary chapel until such time as a proper church could be built. The appropriately-named Our Lady Star of the Sea Church was built in late 1848 with the assistance of the settlers, who supplied labour and materials for the building: timber, nails, and linseed oil; the labour for the glazing and painting. This joint project showed the extent to which the Irish parishioners were willing to work with their new priest towards a common goal. ${ }^{34}$

Following his appointment as parish priest of both Panmure and Otahuhu in early to mid-1848, Garin also set about organizing similar infrastructure for his new parishes. He purchased a horse so that he could reach the other settlements more easily, built a raupo school room in Panmure that was used as a chapel, and asked the Colonial Secretary to mark out land for a Catholic church, school and cemetery at Panmure and Otahuhu. ${ }^{35}$ The land was surveyed by September 1849, and Garin placed an order for wood for the Panmure church in March 1850. He passed subscription money for the church to Bishop Pompallier before leaving for Wellington in April. New Zealand had been divided into two Catholic dioceses in 1848, with the Marists assigned the southern, or Wellington Diocese, and Pompallier the northern, or Auckland Diocese. It was Pompallier who consecrated St Patrick's Church, Panmure, on 14 February $1852 .{ }^{36}$ At Otahuhu, meanwhile, a raupo whare had functioned as the first Catholic church and school from October 1848. This whare was apparently erected on land donated by John Quinton, whose daughter Martha had been the first settler baptized by Garin at Otahuhu. In late 1849 land was marked out for the future church and cemetery at Otahuhu. A more permanent school building was erected in the settlement in February 1850, despite the Marists' imminent move to the Wellington Diocese.$^{37}$ It seems that Garin was able to provide a church infrastructure in a relatively short space of time, even for these small, separate settlements.

Garin further contributed to the maintenance of Catholic identity through the establishment of schools. By late 1848, Catholic schools could be found at all three of his Fencible parishes. Their success is suggested by the fact that the Howick school had 137 pupils, twice as many as the local Anglican school, and also twice as many pupils as Séon's school in Onehunga. Garin's schools at the smaller settlements were also flourishing, with 62 pupils enrolled at Panmure and 22 at Otahuhu. ${ }^{38}$

It was not merely by establishing parish infrastructure that Garin was able to create a strong sense of Catholic consciousness. His residence in the parish was also a contributing factor. When Garin received his presbytery in 1849 , replacing the raupo whare, the reason recorded was that 'this clergyman has resided there from the first establishment of the village'. ${ }^{39}$ Until 1850, no minister from the other denominations resided in the Fencible settlements. Though All Saints' Anglican Church was the first church to be 
opened in Howick, in November 1847, Selwyn chose to have his collegiate deacons minister to the pensioners. The deacons lived at St John's College in Tamaki. ${ }^{40}$ Garin's situation as the only resident minister in Howick appears to have had spiritual consequences. The baptism, marriage and death registers indicate that a number of recantations took place under Garin's ministry. During 1848, a Protestant was rebaptized in the Catholic Church just weeks before his death, two Protestant men became Catholic and remarried their respective spouses in the Catholic Church, and a child was rebaptized Catholic. In 1849 there were six recantations and three children were rebaptized. Another child was rebaptized in 1850, a week before Garin left Auckland. ${ }^{41}$ These instances suggest that Garin was a respected and persuasive priest. It is interesting to note how this evidence contrasts with comments from St Patrick's parish in central Auckland, where Marists JeanBaptiste Petit-Jean and Jean Forest encountered many 'careless' Catholics, which they attributed to irregular marriages that kept people away from communion, or simple indifference. ${ }^{42}$ There are other small signs that point to the respect which Garin was accorded by the Fencibles: it was Garin, for example, who organized an address on behalf of the pensioners of Howick, thanking Doctor Mahon for his services upon his removal to Otahuhu and Onehunga, and had it published in the Daily Southern Cross. ${ }^{43}$

Another defining aspect of Garin and the Fencible Catholics' maintenance of their identity was their emphasis on 'mission': the re-igniting of the faith, and obtaining of new converts. Mission was a characteristic of Catholicism in the nineteenth century and when growing up in France, Garin had been exposed to the Marist missions to the countryside. These celebrations of the faith went beyond church services, to encompass processions, retreats, exercises of the Jubilee and the like. Garin's sense of the importance of mission was likely heightened by the pluralistic nature of New Zealand settler society, in which different denominations had to exist alongside one another. In the first extant entry of his diary from Howick, in December 1849 , Garin wrote that a ceremony was held to bless his presbytery. $\mathrm{He}$ turned the blessing into a school party with afternoon tea for 150 people and a procession of the Howick and Panmure schoolchildren complete with banners. One hundred and twenty children attended. The importance that Garin attached to the occasion can be seen from his decision to create a monument to the day when the Howick and Panmure schoolchildren had to say their farewells. He named the place of their parting 'Union Bridge' - a monument that 'no one could knock over'. ${ }^{44}$ It is perhaps from fellow Marist, Jean Forest, that Garin had the idea to incorporate such events into his parish calendar. The St Patrick's parish in Auckland is recorded as having celebrated St Patrick's Day with a procession and tea party in March 1848, shortly after Garin's arrival in Auckland. ${ }^{45}$ This emphasis on 
mission also meant that visits from the Bishop were particularly important. During an April 1849 sojourn in Howick, Bishop Viard held mass, accepted a recantation and performed a conditional baptism, gave confirmation to 20 pensioners and first communion to six children, distributed prizes to the schoolchildren, and renewed baptismal vows, all on the same Sunday. He repeated this at Panmure a week later. ${ }^{46}$

By going back to his roots, and holding these events in the vein of the missions to the countryside that he had experienced in the Bugey region of France, Garin heightened the presence of the Church in the community and helped to create a specifically Catholic community in Howick. His church was attended by around 120 people, in comparison to just 50 for the similarly-sized settlement of Onehunga. ${ }^{47}$ Garin also understood the importance of respecting the elders in the community, inviting the sergeants to dinner and giving them gifts. By the time of Garin's departure, his cottage had become a focal point of the community. ${ }^{48}$ The bonds he created were strong enough that he stayed in contact with a number of Fencibles long after he had left Howick. He hosted Patrick Corrigan from Panmure at his boarding school in Nelson, exchanged letters with Benjamin Condron - his schoolteacher from Panmure - during the 1850s and with Sergeant James Cleary up to the mid-1860s, and wrote to the new Catholic priest, Henry Fynes, up to the $1880 \mathrm{~s}^{49}$ Other Marists recorded similar experiences with the Irish Catholics in Auckland, as this excerpt from a letter by Jean-Baptiste Petit-Jean suggests: 'I thought I would never get over losing my dear New Zealanders, and yet my heart has taken root among the Europeans. Oh! God, I know that it is going to be hard for me to leave Auckland. I am very attached to my flock, the children at my school are my joy, the Irish delight me with their singular faith. True, there are crosses to bear, but we love them or at least we suffer them patiently because we flatter ourselves that we are overcoming them. ${ }^{50}$

\section{Garin in Nelson, 1850-1889}

There was one major difference between the settlement of Nelson and that which Garin left behind in Howick. While Howick was populated by a large number of Irish Catholic pensioners, most of the immigrants to Nelson had come from England. Phillips and Hearn note that Nelson, as a Wakefield settlement town, had a disproportionately high number of English-born settlers: over $80 \%$ in 1878 . Only $6 \%$ of the United Kingdom-born settlers in Waimea County were Irish. ${ }^{51}$ Garin wrote to his brother that in 1852, of Nelson's 4587 European inhabitants, only 231 were Catholic. The number of Catholics barely surpassed that of persons who had refused to state their religion. There were, on the other hand, more than 2500 Anglicans, 530 Presbyterians, and 529 Wesleyans. Garin and his parishioners could not 
maintain their Catholic identity without taking their new environment into account, and some reworking of this identity was necessary if they were to live in harmony with the general populace.

The clearest way in which Garin's work in Nelson contributed to a distinctive national Catholic identity was through his championing of separate Catholic education. The reassertion of Papal conservatism after the Revolutions of 1848 ensured that Catholic policy regarding state education would be hostile. Pius IX specifically disapproved of what he termed 'godless colleges' ${ }^{52}$ From the time of its inception, then, the Marist Society considered Catholic education as one of its principal aims, second only to mission. ${ }^{53}$ Catholic schools were, in effect, protectors of the faith. Garin brought this cultural baggage with him from Europe: he could not support a state education system that preferred secular education over denominational education, or he would be opposing the Church itself.

Patrick Moran, the Bishop of Dunedin, was another opponent of secular education. His opposition arguably had a higher profile because of his more prominent position and the promulgation of his views through his periodical, the New Zealand Tablet. ${ }^{54}$ But it was Garin who first brought the issue to provincial and national attention, following the establishment of a provincial education system in Nelson in 1856. Garin was vociferous in his opposition to the Nelson Education Act and its provision of secular education in Nelson, and he used the letters columns in the Nelson Examiner to express the Catholic point of view. He led the campaign against the Act, writing at least 50 letters to the editor in the 11 years that the debate continued. He wished to keep a Catholic school, with Catholic teachers, and equipped with history and geography books in which the history of Europe since the times of Luther was not represented from the Protestant point of view. The latter might seem a pedantic point, yet some years later Garin illustrated the problem using a geography book which gave the following description of the governance of Italy: 'The present race, though famous for painting, sculpture, and music, has long been in a degraded condition under the government of the Popes, and other tyrannical and superstitious rules. ${ }^{55}$

In response to the Catholic community's opposition, Nelson's Central Board of Education proposed the introduction of a scheme used in Canada which allowed for a minority of ratepayers in any educational district to take their portion of the rate out of the common fund, and use it to form a separate school, denominational or otherwise..$^{56}$ An amendment to the provincial legislation was passed in 1858 that allowed the establishment of denominational schools within the public system by a group of ratepayers contributing not less than $£ 50$ per annum to the rates levied under the Act. These were to be known as 'separate schools' ${ }^{57}$ Garin did not avail himself 
of the amendment: he believed that he had yet to win the right of choosing his own books and teachers. It became one of the debating points in the 1867 elections for the Nelson superintendency. In the event, an amendment suggested by candidate and eventual Superintendent Oswald Curtis, was made to the Education Act. The amendment stated that the subscription to rates required from a group that wished to create a separate school was to be halved to $£ 25$, and the assistance given by the Central Board to the separate school was to be made in the form of money only. In 1867, after 11 years of campaigning, Garin announced that he would be placing his schools under the Act. ${ }^{58}$

By their struggle to keep separate Catholic schools, Garin and the Catholic community helped to maintain a distinctive Catholic identity. First, as Garin noted to a local parishioner, it was through school that children had access to their priest: if there was no school, the children would be 'little strangers to their pastors'. Garin also believed that without the schools, the Catholics in Nelson would be nearly invisible, 'drowned and swept along in a multitude of Protestants; seeing themselves as one of them, they wouldn't even want to be known as Catholics, and would live like Protestants'. ${ }^{59}$ At stake was the maintenance of intergenerational faith. Garin and the Catholics thus represent a force of resistance to the processes of nationbuilding that tend to suppress minorities and lead to the erasure of difference in the community. Their success can be attributed in part to Garin's particular ability to find practical solutions and take a non-extremist stance. In this he was quite unlike Bishop Moran, who tried to forbid Catholics from sending their children to public schools altogether. ${ }^{60}$

The consequences of Garin's fight for Catholic education in Nelson were felt beyond the confines of the community. Education was a national issue, and the 'Nelson compromise' became well-known throughout the country. On hearing that the General Assembly wanted to propose a uniform education system for all of New Zealand, Garin began working to ensure that the Nelson Education Act Amendment Act 1867 was made into a piece of national legislation. There were two provisions that he considered vital. First, there should be no Bible reading or religious instruction in public schools, so that no controversy would arise over which version of the Bible should be used or the religious persuasion of the teacher. Second, separated schools should be formed on the same terms that he enjoyed in Nelson. ${ }^{61}$ Ultimately, the Act that was passed by the House of Representatives in 1877 instituted completely secular education, with no Bible-reading in schools. ${ }^{62}$ Indirectly, the Nelson system had exercised a 'powerful influence in helping to mould the national system'. ${ }^{63}$ After 1877, many Catholics withdrew their children to their own schools which continued to flourish - a legacy which is present in New Zealand today. 
An addition to Garin's schools, which highlighted the Catholic difference, was the establishment of orphanages. Garin believed that Catholic children who had been orphaned and admitted to state-run institutions were brought up as Protestants. During a visit to Golden Bay, probably in November 1871, Garin's curate J. Nicolas Binsfeld had discovered a number of Catholic children at an orphanage in Motueka. ${ }^{64}$ In early 1872 Garin received permission from Superintendent Curtis to claim Catholic orphans, such as those at Motueka, and bring them to Nelson under the care of St Mary's Catholic station. ${ }^{65}$

Thus began St Mary's Orphanage. Originally the boys were cared for by a matron at the station and the girls by the Sisters at the convent, and all the children attended parish schools. Then, in 1879, Garin applied to the Colonial Secretary to have St Mary's Orphanage deemed an 'industrial school' under the Neglected and Criminal Children's Act (1867) ${ }^{66}$ St Mary's was so constituted, being the first denominational institution of the kind to be established by law. Industrial schools could take orphan children, neglected children, homeless children, or any child who had committed a crime but whom the justices believed should be sent to an industrial school rather than a prison. Though originally a provincial establishment, an amendment to the Neglected and Criminal Children's Act in 1881 stipulated that the schools could accept any child in New Zealand committed by a magistrate. It was at Garin's instigation that the member of parliament for Waimea, Joseph Shephard, worked to have this amendment passed in the House. ${ }^{67}$ Thereby St Mary's Industrial School became the first denominational industrial school for boys and girls in New Zealand. ${ }^{68}$

At this point Garin effectively began to care for two different categories of children: orphans and neglected children. He chose to house them in separate buildings, so that he had boys' and girls' orphanages, and boys' and girls' industrial schools. ${ }^{69} \mathrm{~A}$ farm was purchased near Nelson to house the orphan boys, to be staffed by Marist teaching Brothers. As was often the case with the Nelson parish, the Stoke Industrial School, though Garin's idea, was a community effort. Prominent members of the Catholic community, such as Garin's close friend Judge Lowther Broad, organized the business aspects, while Bishop of Wellington Francis Redwood took a particular interest in developments. ${ }^{70}$ It was completed in 1886. As Bishop Moran said in the New Zealand Tablet, 'the erection of this grand building is a matter for congratulation among the Catholics throughout the Colony, and particularly in the Diocese of Wellington. ${ }^{71}$ By 1893, of the 503 Catholic children in Catholic orphanages, 315 of them were at Stoke Industrial School in Nelson. ${ }^{72}$ Again, education had brought the Catholic difference to light.

Of course, Garin did not only bring to Nelson the idea of denominational education, but also a whole system of Marian beliefs and practices that 
had been inculcated during his noviciate in France. In the climate of postRevolution France, when Christianity was in an expansive mode, the Marist Society had formulated three principal aims: education, mission and the defence of the Catholic faith, with an overlying focus on a compassionate approach to their apostolate. The situation Garin encountered in Nelson was reminiscent of the Marist missions to the countryside in the 1820s: scattered populations, with limited access to the infrastructure of the Church. For Garin, education did not merely mean the creation and maintenance of Catholic schools and orphanages. He was keenly aware of the danger that Catholic children brought up in a predominantly Protestant country would lose their faith, and thus placed great importance on reaching as many children as possible through Sunday school teaching and catechism. Children in Waimea were unable to attend the Catholic school in Nelson unless they could afford to live as boarders. Garin thus devised a system of weekly visits for catechism. In order to motivate the children he would give them 'bons points', or paper money, for good work, which they could use at the end of the school year to buy Catholic books and pictures. ${ }^{73}$ At the end-of-year examinations, he would decorate the respective churches, and display the pictures and books that were up for sale. Children who recited the Bible with the least mistakes or gave the best replies to the catechism questions were allowed to choose their prize; an auction was then held so that all children could spend the 'money' they had accumulated during the year. Garin believed that 'this competitiveness produces the most marvellous effects' ${ }^{74}$

Another means by which Garin reinforced the children's Catholic identity was by organizing school 'tea parties', which usually consisted of a parade with flags, sometimes oral examination of the children, and then tea and games. The tea parties could be attended by several hundred people, including some of Nelson's leading citizens. Garin put great thought and effort into these parties, which were in direct competition with those that the public schools held, and they often had a touch of French flair. In 1871, after 20 years of the parties, the Colonist recorded that 'the French game of Chicken in the Pot was highly amusing'. The parties were also an opportunity for Garin to indulge the children in his own interests, such as music and singing, and all things modern. His magic lantern was reputedly one of the biggest in Nelson, and made images that were five centimetres high appear a metre high; other examples of modern entertainment included stereoscopic views and a galvanic battery, used to make engravings. ${ }^{75}$ For the twenty-sixth anniversary of St Mary's Schools in 1876, Garin took the children by train to Wakefield. For many of them it was their first ride on a steam train. ${ }^{76}$ School picnics and church openings were some of the few events that women and children could participate in ${ }^{77}$ and Garin's knack for 
providing interesting entertainment made them a focal point on the Catholic calendar.

Exterior signs of the faith were also the essential ingredient in 'mission'. Church-building was one of the most obvious of these exterior signs, providing the setting for celebrations of the faith. The first Nelson churches, Sts Peter and Paul in Waimea West, and St Mary's in Manuka Street, were built in 1855 and 1857 respectively. Much of the post-1860 church-building was owed to the influx of miners to Nelson Province. Gold was discovered first in Golden Bay in the mid-1850s, then the Buller and Lyell Rivers in the early 1860s, and in 1864 at Wakamarina, east of Nelson town. ${ }^{78}$ Over the winter of 1864 the Wakamarina miners retired to Nelson and crowded Garin's church. With the subscriptions of these miners, including those of the West Coast, an addition to the Nelson church was made in 1865 and a handsome steeple built, with a gilded ball and cross to commemorate the miners' generosity. The Catholic bell tower, nicknamed 'the miners' tower' because they had financed it, was the highest building in Nelson. ${ }^{79}$ Other collections enabled the doubling in size of the church at Waimea in 1865, and the building of Sacred Heart Church at Takaka in 1868, St Joseph's Church at Wakefield in 1870, St Francis's at Motueka in 1876, and a church at Hampden (present-day Murchison) in 1882. This was in addition to the rebuilding of St Mary's in Nelson following a devastating fire in $1881 .{ }^{80}$ By 1882 the parish of Nelson contained six Catholic churches in addition to its schools and orphanages, despite the relatively small numbers of Catholics in the province who were able to fund them.

The Catholic emphasis on exterior signs of the faith was evident in the European touches that Garin brought to his churches. He imported church ornaments from Europe, sending long lists of pictures, crosses and decorations that he would like, as well as more particular requests such as his church bell. ${ }^{81}$ The style of service at St Mary's was similarly European, with a focus on music and ceremony. Garin was a competent musician, who could play a variety of instruments including the flute, clarinet and harmonium, and he held singing lessons for the school children, a class that was 'spoken quite highly of in town' and from which his church benefited. Every Sunday there was a sung high mass; according to Garin, 'Our music is generally considered to be the best in the place. ${ }^{82}$

Garin believed that a vital part of enlarging his Catholic community was the encouragement that mission visits could bring, in the style of the French missions to the countryside. He constantly sought visits from his bishops, whom he needed to encourage baptisms, conduct confirmations, and add importance to ceremonies such as the blessing of churches. Unfortunately, Bishop Viard took a passive approach to his provincial duties, preferring to be fully involved in the care of the Wellington parish at the expense of 
the rest of the diocese. ${ }^{83}$ However, Garin secured a three-week long visit from Viard in June 1857 to celebrate the opening of his new churches and give confirmation to the parishioners of Nelson and Waimea. In 1866 the Bishop made a second visit with the original visiting priest of Nelson, Jeremiah O'Reily. Garin had the details of O'Reily's happy reunion with his parishioners published in the Colonist. ${ }^{84}$ The appointment in 1874 of Viard's successor, Francis Redwood, whom Garin had taught as a young boy, ensured that episcopal visits for celebrations and mission work became more frequent. Other examples of this more proactive style of Catholicism included the exercises of the Jubilee that Garin and his curate, William Mahoney, held in 1851 and 1875 respectively. ${ }^{85} \mathrm{He}$ also hosted missions given by visiting evangelists such as Father Patrick Hennebery, who revived Catholic commitment and promoted a pledge against drinking. Hennebery held a week-long mission in Nelson in October 1878, at which Redwood presided to give confirmations and another Marist, Augustin Sauzeau, assisted as confessor. The effects of such missions in reviving the faith were indisputable: during Hennebery's visit 300 people took the pledge, and there were 300 communions, 21 baptisms, and 78 confirmations. ${ }^{86}$

Given the particular geographical nature of the Nelson parish, Garin considered that gathering his scattered flock was another essential aspect of his mission. As he noted, he only had direct access to approximately one-third of his parishioners in Nelson town. The other two-thirds were split between Marlborough on the one hand, and Waimea and Motueka/ Golden Bay on the other. ${ }^{87}$ From an analysis of Garin's diary and the baptism registers that he kept, it appears that he visited Motueka six times between 1851 and 1857; following the gold rush, he extended these trips to encompass Golden Bay, which he also visited six times. This was in addition to the annual visits that he undertook over a ten-year period to Marlborough. While the visits to Motueka were only of three to four days' duration, those to Golden Bay could last up to three and a half weeks, and those to Marlborough could take from four to 11 weeks depending on whether he also visited the Kaikoura coast. As Garin explained to his brother regarding the division of work with his curate, 'one goes to bring the members of the flock that have strayed back to the fold, or bring others into it who have never been in it before, while the other acts as sentry so that those already in the fold don't leave it'. ${ }^{8} 8$

For the Catholics who Garin saw in these remote areas, his visits provided the opportunity to put a human face to the Church, beyond the correspondence that they had with their priest throughout the year. The priest's visits marked life's great events. On his first visit to Marlborough in 1853, Garin baptized 26 children, married two couples, and remarried a further two. ${ }^{89}$ On 27 March 1856, he said the first ever mass in Marlborough, 
at the McDonalds' house in Boulder Bank. During his travels, he taught the children their catechism, heard confessions, said prayers and mass at private houses, and taught the children to read in the more isolated settlements such as Te Awaiti. Some parents waited anxiously for his visits, wanting him to baptize their children. He also had to convince families to continue bringing their children up as Catholics in settlements such as Motueka, where there was a Protestant church and Sunday school freely available, but no Catholic infrastructure.$^{0}$ Garin's visits were vital to maintaining the faith of the Catholics in the more remote parts of his parish. He backed these visits up with other measures, such as creating two circulating Catholic libraries a town library and a country library - and organizing subscriptions to Catholic publications like the Freeman's Journal on behalf of his parishioners. This kept them in touch with Catholic values, and provided them with a sense of collective identity. ${ }^{11}$ The number of conversions to Catholicism was a tribute to the emphasis which Garin and his curates placed on mission. According to an article in the New Zealand Tablet in 1880, the Catholic population of Nelson had the peculiarity that more than half of the Catholics were converts. In Garin's first ten years in Nelson there were 26 conversions, while in the years 1875 to 1880 his assistant Mahoney received over 40 converts, including a man whose father had been Moderator of the Free Church of Scotland..$^{92}$

The final, and essential ingredient of the Marist philosophy that Garin sought to follow in Nelson was the defence of the Catholic faith. In addition to the Hibernian societies that he helped to found in Nelson and Blenheim, ${ }^{93}$ Garin defended Catholicism through an extensive correspondence with the editors of local newspapers. He kept an index book for recording his letters to the editor, and it is apparent that after 1858 - the year in which the amendment to the Nelson Education Act was passed which defused the education issue - the majority of letters that he wrote to the newspapers were replies to articles which slandered the Catholic Church. ${ }^{94}$ Many of the articles made claims so outrageous they were easily refuted: that the French government opposed the circulation of the Bible because it was immoral; that a Catholic priest had been imprisoned for reading a German Bible; that Jewish children were being forcibly baptized in Rome. Some letters dealt with issues that touched Garin personally. When the Nelson Examiner published an article likening the Jesuits - whom the Marists had modelled themselves on - to the Mormons, Garin wrote defending the Jesuits and provoked a stack of letters 'a foot high', according to the editor. ${ }^{95}$ Other letters provide food for thought even today. When an article in the Examiner alleged that the French missionaries had been used by the French government to colonize the Pacific Islands, whereas the Protestant missionaries had been instrumental in Christianizing the Pacific Islanders, Garin wrote: 
This mode of narrative, by which it represents French missionaries as instrumental for 'colonizing', and Protestant missionaries as 'Christianizing', seems to me to be dictated by rather unfair and prejudiced feelings. In the case of any such distinction, I think the reverse would have been more obvious to the position of both parties; for it is well known that the French government has no spiritual power in the Catholic Church, and is therefore unable to send missionaries to any part of the world; but, on the contrary, Protestant missionaries generally having their spiritual head connected with their government, they may be sent by it as instruments of colonization.

Garin then proceeded to give the French version of events in Tahiti, under the pseudonym 'Hear Both Sides'. In this, Garin sought to show the majority Protestants that they would not like to be treated as the Catholics were. ${ }^{96}$ As Marist Visitor-General Victor Poupinel noted after his first tour of New Zealand, Garin did not let himself be discouraged by the minority position that he found himself in: 'he energetically defends his rights in the newspapers, and, through his friends, in public fora. He has real influence, he is respected and esteemed'. ${ }^{97}$

Garin was a leader who took all possible measures to reinforce the identity of his community, maintaining a Catholic diasporic distinctiveness. His zealous efforts did not go unnoticed by Nelsonians. As 'A Protestant' wrote to the Nelson Evening Mail:

The remarkable developments of the Roman Catholic propaganda in our midst call for serious thought. While we have been quietly relegating the ancient faith to the limbo of exploded absurdities, lo! A Phoenixlike resurrection bursts upon us until we have to confess what stands forth as a solemn truth today that the only religious community in our neighbourhood which is really instinct with life is this venerable anachronism of Roman Catholicism. [. . .] In the Old Home today there are hundreds of husbands who are mourning as worse than dead their entangled wives, and parents their children. They toyed with the velvet paw as our Nelsonians do, and, like the late Dr Wilberforce, woke up at last to see their dearest ones hopelessly fixed by the relentless claws. [. . . I It would be an impertinence for me to speak of the personal excellences of the ladies and gentlemen who are at the head of our Nelson Roman Catholic propaganda. Their adherents are among our best citizens, and their various good works are a rebuke to our self-seeking and want of zeal. As the visitor to our charming city glances over the amphitheatre which constitutes its area, with its environment of hills, from the Port road, he will see two magnificent sites crowned with ecclesiastical buildings. If he should happen to be of the Romish faith he will learn with infinite satisfaction that the elegant structure to the 
left is a Roman Catholic Church, and if he should be a worthy son of the English Church he will hear with amazement, dashed with shame, that the indescribable monstrosity which obtrudes itself from the other unique site is the Cathedral Church of the Nelson diocese! ${ }^{98}$

Garin was also a man who could win respect from all sections of the community, even if he was described as 'a most unusually amiable representative of a most illiberal and persecuting sect'. ${ }^{99}$ This was the key to his success in what was one of the least Catholic parts of the country. Some local Protestants admired the Catholic clergy's self-denial and their dedication to visiting among their parishioners, and lashed out against their own clergy, too many of whom, they believed, contented themselves with 'delivering stale platitudes from the pulpit'. ${ }^{100}$

\section{Conclusion}

The minutiae of everyday life that Garin recorded in his various diaries, letters and annals tell the story of the community-building that took place in the parishes of Howick and Nelson in the mid- and late-nineteenth century. Garin and the Catholics with whom he worked brought a shared experience of European Catholicism with them to New Zealand. Like more widely recognized diasporic groups, such as the Irish, they sought to maintain this identity in the new environment, and recognized the need to compromise on some of their principles, such as denominational education, in order to live harmoniously within the wider community.

I began this paper by suggesting that religion, especially where religious groups are in a minority position in their adopted country, is more than a 'cognate phenomenon' to diaspora. Rather, religion can be a source of diasporic consciousness for groups within a host nation. While in the case of Howick it appears that the Pensioners' Catholic identity was cognate to their identity as members of the Irish diaspora, in the case of Nelson, Catholic identity subsumed ethnic identity as a source of community. A study of Garin's Catholic communities in Howick and Nelson demonstrates the usefulness of extending diaspora concepts beyond ethnicity to include other vital elements of cultural make-up, such as religion. Applying the concept of diaspora in relation to both ethnicity and religion enriches explanations of the human impact of migration in historically-specific contexts.

The New Zealand case is illuminating. The New Zealand Catholic Church was a melting pot of French, English, Scottish and Irish influences. 'Ethnic' loyalties competed with more pressing loyalties such as religion, family, class, and locality. ${ }^{101}$ A fellow Catholic, in the sea of Anglicans that characterized nineteenth-century New Zealand, was less a stranger than they were. In the same way, the local Catholic school, local Catholic church, local Catholic priest, local Hibernian society and the international Catholic newspapers 
were less 'strange' than the exclusive English institutions which became the ruling institutions for the whole society. These 'old-world lumps', as James Belich describes them, could and did survive the migration process. When fostered by community leaders like Garin, they reduced the atomism that Miles Fairburn sees as endemic to nineteenth-century New Zealand society. ${ }^{102}$

As parish priest of Howick and Nelson, the leader of a minority group, Garin expressed his identity in the new land by asserting Catholics' cultural distinctiveness. He fought to gain a place for Catholics in New Zealand settler society, a society in which the dominance of the Protestant population threatened to overwhelm the Catholic presence. The new country provided Garin with the opportunity to become the leader of a small community of Catholics and a voice on Catholic issues. His efforts brought about vibrant parish communities that were recognized as such by outside observers. Constructing communities as Garin did is, moreover, a vital part of the migrant experience. As Nikos Papastergiadis concludes in The Turbulence of Migration, the need to construct communities is a deep and universal feature of the human condition. ${ }^{103}$

1 J. Coste, Lectures on Society of Mary History, Rome, 1965, p.107.

2 For recent critical analyses of Garin and his work, see Hélène Serabian, 'Le journal du Père Antoine Garin, 1844-1846: une édition critique présentée avec commentaire, transcription et annotations', $\mathrm{PhD}$ thesis, University of Canterbury, 2005; and Giselle Larcombe, 'Antoine Marie Garin: A Biographical Study of the Intercultural Dynamic in Nineteenth-Century New Zealand', PhD thesis, University of Canterbury, 2009. Both are available in the University of Canterbury online Research Repository. For an earlier biographical sketch, see Mary Catherine Goulter, Sons of France, Wellington, 1958, pp.72-95.

3 Miles Fairburn, The Ideal Society and its Enemies: The Foundations of Modern New Zealand Society, 1850-1900, Auckland, 1989, pp.11, 181-3.

4 This paper provides support to John Stenhouse's argument for the influence of (Protestant) Christianity on early New Zealand society and politics. See Stenhouse, 'God's Own Silence: Secular Nationalism, Christianity and the Writing of New Zealand History', New Zealand Journal of History (NZJH), 38, 1 (2004), pp.52-71. I would also like to take this opportunity to thank the referees of this paper, whose insightful and interesting comments allowed a more polished version of the paper to emerge, and who also provided food for thought for future publications.

5 Monika Fludernik, 'The Diasporic Imaginary: Postcolonial Reconfigurations in the Context of Multiculturalism', in Monika Fludernik, ed., Diaspora and Multiculturalism: Common Traditions and New Developments, Amsterdam, 2003, p.xi.

6 Malcolm Campbell, 'Diasporas', NZJH, 37, 2 (2003), pp.125-9.

7 Robin Cohen, Global Diasporas: An Introduction, London, 1997, pp.180-4.

8 Fludernik, pp.xii-xiii. John Hutnyk asserts that turning the lens of diaspora onto the study of whiteness confronts issues of racial inequality, posing the question of why it is 
that the movements and settlements of people of colour have attracted so much attention in the literature on diaspora. Whiteness only makes an appearance in discussions of those who do not quite fit into the Anglo-Saxon version of normality, such as the Jews and the people of the Mediterranean, whom Hutnyk describes as being of 'secondary whiteness'. The Irish are an example of the 'white but not quite' who have been commonly considered a diaspora. See Virinder S. Kalra, Raminder Kaur and John Hutnyk, Diaspora \& Hybridity, London, 2005, pp.2-3, 106-7, 115.

9 Vron Ware and Les Back, Out of Whiteness: Color, Politics, and Culture, Chicago, 2002, p.128, cited in Kalra, Kaur and Hutnyk, p.107.

10 Kalra, Kaur and Hutnyk, pp.113-15. A number of works have been published on New Zealand's Irish and Scottish migrants by Angela McCarthy, Brad Patterson, and Lyndon Fraser among others, while an important book covering the experience of the English settlers in addition to the Irish and Scots has been released by Jock Phillips and Terry Hearn. Their work highlights the experience of individual settlers as opposed to the collective approach of traditional works on the English imperial enterprise, and is a vital contribution to the study of the English, Irish and Scots immigrants as diaspora in the vein of Fludernik and Hutnyk. Rosalind McClean, in her study of the applicability of diaspora to British settlement overseas, with specific reference to New Zealand, has also suggested that diaspora studies offer a fruitful approach to recover individual stories of migration that have become lost in collective narratives. See Jock Phillips and Terry Hearn, Settlers: New Zealand Immigrants from England, Ireland and Scotland 1800-1945, Auckland, 2008; and Rosalind McClean, " "How We Prepare Them in India”: British Diasporic Imaginings and Migration to New Zealand', NZJH, 37, 2 (2003), pp.131-51.

11 Steven Vertovec and Robin Cohen, eds, Migration, Diasporas, and Transnationalism, Northampton (MA), 1999, p.xxvi. Vertovec provides an example of a diaspora expert content to use 'diaspora' to describe religions in his work on South Asians.

12 Phillips and Hearn, pp.176, 182-4.

13 Cohen, pp.184-7.

14 Fludernik, p.xv.

15 Campbell, p.126.

16 McClean, pp.137-8.

17 Paul Gilroy, There Ain't No Black in the Union Jack: The Cultural Politics of Race and Nation, London, 1987, cited in James Clifford, 'Diasporas', Cultural Anthropology, 9 (1994), pp.302-38.

18 James Clifford, Routes: Travel and Translation in the Late Twentieth Century, Cambridge (MA), 1997, p.44.

19 Irish University Press Series of British Parliamentary Papers: Colonies, New Zealand (GBPP), 1847, V, pp.472-9.

20 GBPP, 1850 [1136], VI, p.140; 1851 [1420], VII, p.146.

21 Ruth Alexander, The Royal New Zealand Fencibles, Auckland, 1997, p.17.

22 Terry Hearn, 'Irish Migration to New Zealand to 1915', in Lyndon Fraser, ed., A Distant Shore: Irish Migration and New Zealand Settlement, Dunedin, 2000, pp.55-74.

23 GBPP, 1849 [1120], VI, pp.21-22.

24 Lillian G. Keys, Philip Viard, Bishop of Wellington, Christchurch, 1968, pp.50, 52.

25 Garin to Numa Garin, 3 March 1853, Epistolae (New Zealand) Z 208, Archivi dei Padri Maristi (APM), Rome. 


\section{Journal of New Zealand Studies}

26 George Augustus Selwyn, 'New Zealand. Part V, A Journal of the Bishop's Visitation Tour through his Diocese, Including a Visit to the Chatham Islands in the Year 1848', in Project Canterbury http://anglicanhistory.org/nz/spg20.html; New Zealander, 29 March 1848.

27 Lyndon Fraser, Castles of Gold: A History of New Zealand's West Coast Irish, Dunedin, 2007, p.18.

28 Hugh Laracy, 'Bishop Moran: Irish Politics and Catholicism in New Zealand', Journal of Religious History, 6 (1970), pp.62-76.

29 Résumé de la correspondance de l'abbé Garin, folios 25-6, Garin dossier, APM.

30 New Zealander, 27 November 1847; Daily Southern Cross, 19 May 1849; Alan La Roche, Personal Communication, 7 August 2007.

31 Notes sur la mission (NM), 26 February, 18 March, 15-17 April 1850, Garin dossier, APM.

32 For an insight into Hugh Coolahan and his role in early Auckland, see Gabrielle Fortune, 'Hugh Coolahan and the Prosperous Irish: Auckland, 1840-1870', MA thesis, University of Auckland, 1997.

33 New Zealander, 20 May 1848; New Zealander, 24 May 1848.

34 Roman Catholic Receipt Book 1848-1873, Auckland Catholic Diocesan Archives (ACDA), cited in Alexander, pp.60-61.

35 Garin to Governor Grey, 18 July 1848, Internal Affairs (IA) 1, 48/1639, National Archives (NA), Wellington; Résumé de la correspondance de l'abbé Garin, folio 26, Garin dossier, APM; Forest to Colonial Secretary, 31 January 1849, IA 1, 49/266, NA; Garin to Colonial Secretary, [n.d.], Ledger 7, Correspondance 1848, St Mary's Parish Archives (SMPA), Nelson.

36 NM, 14 March, 18 April 1850, Garin dossier, APM; New Zealander, 14 February 1852.

37 Otahuhu Centennial Celebrations Committee, A Century of Progress, 1848-1948: A Souvenir of Otahuhu Yesterday and Today, Otahuhu, 1948; Bruce Ringer, Manukau's Journey: A Manukau Timeline, http://manukau.infospecs.co.nz/journey/home.htm; Blue Book of Statistics 1848, IA 12/9, Micro 703, NA; Alexander, p.95; Otahuhu Church Register, RA 15-1, ACDA; Garin to Captain Hickson, [n.d.], Mr Ormsby to Garin, 19 September 1849, Ledger 7, Correspondance 1849, SMPA; NM, 12, 18 February 1850, Garin dossier, APM.

38 Blue Book of Statistics 1849, IA 12/10, Micro 703, NA.

39 Viard to Colonial Secretary, 12 February 1849, IA 1, 49/339, NA.

40 Nelson Blake, 'The Royal New Zealand Fencibles', Historical Journal: Auckland-Waikato, 32 (April 1978), pp.17-21, Allan K. Davidson, Selwyn's Legacy: The College of St John the Evangelist, Te Waimate and Auckland, 1843-1992: A History, Auckland, 1993, p.64.

41 Howick Church Register, RA 7-1, ACDA; Alan La Roche, Personal Communication, 7 August 2007.

42 E.R. Simmons, Pompallier: Prince of Bishops Auckland, 1984, p.104.

43 Daily Southern Cross, 17 March 1849.

44 NM, 8 December 1849, Garin dossier, APM.

45 New Zealander, 18 March 1848.

46 Bishop Viard Journal Intime 1849-1854, 21-23, 29 April 1849, Bx 188, Wellington Archdiocesan Archives (WAA); Howick Church Register, RA 7-1, ACDA. 
47 Forest to Colonial Secretary, 31 January 1849, IA 1, 49/266, NA.

48 Panmure Church Register, RA 16-1, ACDA; NM, 18, 24 February 1850, Garin dossier, APM.

49 NM, 4, 20 December 1854, Garin dossier, APM; Letter Registers. Copies or Summaries of Letters Written by Father Garin, 1852-1875, DNM 2/32, SMPA; Letter Registers. A Second Volume of Correspondence Record, 1875-1888, DNM 2/33, SMPA.

50 Charles Girard, Lettres reçues d'Océanie par l'administration générale des pères maristes pendant le généralat de Jean-Claude Colin: Édition critique, Paris, 2009, II, doc. 298, Petit-Jean to Girard, 8 December 1843.

51 Phillips and Hearn, pp.145, 158.

52 Hugh Laracy, 'Paranoid Popery: Bishop Moran and Catholic Education in New Zealand', in John Hinchcliff, ed., Perspectives on Religion: New Zealand Viewpoints 1974: A Selection of Essays Given at a Colloquium Held at the University of Auckland, New Zealand, in August 1974, Auckland, 1975, pp.9-14; Nelson Examiner, 5 May 1858.

53 J. Coste, Lectures, pp.223-4.

54 See, for example, Laracy, 'Paranoid Popery', p.9; B.D. McLeod, 'Good Reading Matter: The New Zealand Tablet, 1873-1895', in John Stenhouse and Jane Thomson, eds, Building God's Own Country: Historical Essays on Religions in New Zealand, Dunedin, 2004, pp.96-112.

55 Nelson Examiner, 5 June 1866.

56 Nelson Examiner, 11 February 1857.

57 Education Statutes of New Zealand 1844-1877, II, pp.34-37.

58 Nelson Examiner, 2 March, 20 June 1867.

59 Garin to Goulter, 29 January 1864, Letter Registers. Copies or Summaries of Letters Written by Father Garin, 1852-1875, DNM 2/32, SMPA; Garin to Favre, 9 May 1862, Epistolae (New Zealand), Z 208, APM.

60 Laracy, 'Paranoid Popery', p.9.

61 Garin to Viard, 18, 21, 23, 31 August 1871, Letter Registers. Copies or Summaries of Letters Written by Father Garin, 1852-1875, DNM 2/32, SMPA.

62 A.E. Campbell, Educating New Zealand, Wellington, 1941, p.47.

63 A.G. Butchers, Education in New Zealand: An Historical Survey of Educational Progress Amongst the Europeans and the Maoris Since 1878; Forming with 'Young New Zealand' a Complete History of Education in New Zealand from the Beginning of the Nineteenth Century, Dunedin, 1929, p.87.

64 Garin to Reilly, 14 October 1871, Letter Registers. Copies or Summaries of Letters Written by Father Garin, 1852-1875, DNM 2/32, SMPA; Garin to Binsfeld, 12 October 1881, Letter Registers. A Second Volume of Correspondence Record, 1875-1888, DNM 2/33, SMPA; Historical Documents, HD6, folios 165-7, Marist Archives (MAW), Wellington.

65 Annals of the Catholic Station Established in Nelson, New Zealand, 9 May 1850, DNM 2/31, folio 164 , SMPA.

66 Garin to Colonial Secretary, 2 October 1879, Letter Registers. Copies or Summaries of Letters Written by Father Garin, 1852-1875, DNM 2/32, SMPA.

67 Garin to Shephard, 27 June, 22 September 1881, Letter Registers. A Second Volume of Correspondence Record, 1875-1888, DNM 2/33, SMPA.

68 New Zealand Tablet, 14 October 1881. 


\section{Journal of New Zealand Studies}

69 Garin to Numa, 10 October 1883, Epistolae (New Zealand), Z 208, APM; Garin to Hislop, 1 November 1881, Letter Registers. A Second Volume of Correspondence Record, 1875-1888, DNM 2/33, SMPA.

70 Garin to Redwood, 5 June 1884, Letter Registers. A Second Volume of Correspondence Record, 1875-1888, DNM 2/33, SMPA.

71 New Zealand Tablet, 27 August 1886.

72 Michael O'Meeghan, Steadfast in Hope: The Story of the Catholic Archdiocese of Wellington 1850-2000, Palmerston North, 2003, p.158; Butchers, p.78.

73 Garin to Favre, 20 April 1857, Epistolae (New Zealand), Z 208, APM.

74 Garin to Poupinel, 18 February 1858, Epistolae (Villa Maria), VM 222, APM.

75 NM, 7 January 1851, 7 January 1852, 17 January 1868, 18 January 1871, Garin dossier, APM; Colonist, 20 January 1871; Garin to Numa Garin, 5 February 1866, Epistolae (New Zealand), Z 208, APM.

76 New Zealand Tablet, 19 May 1876.

77 Jim McAloon, Nelson: A Regional History, Whatamango Bay, 1997, p.53; NM, 22 January 1862, Garin dossier, APM.

78 Garin to Numa Garin, 7 July 1858, 22 June 1865, Epistolae (New Zealand), Z 208, APM; McAloon, pp.61, 75-6.

79 Garin to Numa Garin, 22 June 1865, Epistolae (New Zealand), Z 208, APM.

80 Garin to Redwood, 8 August 1865, Bx 211, WAA, Historical Notes; Census Statistics of New Zealand, Return of Places of Public Worship in April, 1881, DNM 9, SMPA.

81 Garin to Germain, 12 September 1879, Superiores, Z 618 410, APM.

82 Moreau to Colin, 3 March 1852, Epistolae (New Zealand), Z 208, APM; Edward Clisby ed., Letters from Oceania: Letters of the First Marist Brothers in Oceania, Rome, 1999, IV, doc. 122, Claude-Marie to Redwood, 8 December 1857; Garin to Numa Garin, 17 August 1859, Epistolae (New Zealand), Z 208, APM.

83 Garin to Poupinel, 14 February 1866, Superiores, Z61 8 410, APM; O’Meeghan, pp.94-95.

84 Annals of the Catholic Station Established in Nelson, New Zealand, 9 May 1850, DNM 2/31, folio 55, SMPA; Colonist, 10 July 1866.

85 NM, 8 June 1851, Garin dossier, APM; Annals of the Catholic Station Established in Nelson, New Zealand, 9 May 1850, DNM 2/31, folio 192, SMPA.

86 Hugh Laracy, 'Patrick Hennebery in Australasia, 1877-1882', in Brad Patterson, ed., The Irish in New Zealand: Historical Contexts and Perspectives, Wellington, 2002, pp.103-16; Annals of the Catholic Station Established in Nelson, New Zealand, 9 May 1850, DNM 2/31, folio 211, SMPA.

87 Garin to Viard, 21 September 1860, Superiores, Z 618 410, APM.

88 NM, 1851-1863, Garin dossier, APM; Garin to Numa, 4 August 1851, Epistolae (New Zealand), Z 208, APM.

89 NM, 21 January-25 February 1853, Garin dossier, APM.

90 NM, 15-17 January, 20 February 1855, 20, 27 March 1856, Garin dossier, APM.

91 Moreau to Poupinel, 3 April 1860, Epistolae (Villa Maria), VM 222, APM; Garin to Poupinel, 4 September 1867, Epistolae (Villa Maria), VM 222, APM; Peter Gibbons, 'The History of Mr Andersen's Writing: Discourse and Author/ity in a Settler Society', 


\section{Religion and Diaspora}

in Catharine Coleborne, Mark Houlahan and Hugh Morrison, eds, Telling Lives: Essays in Biography and History, Hamilton, 2006, pp.29-43.

92 New Zealand Tablet, 3 September 1880; Garin to Viard, 21 September 1860, Superiores, Z 618 410, APM.

93 Garin to Binsfeld, 21 September 1875, Letter Registers. A Second Volume of Correspondence Record, 1875-1888, DNM 2/33, SMPA; Marlborough Express, 19 February 1876. For further information on the Hibernian Society in New Zealand see Rory Sweetman, Faith and Fraternalism: A History of the Hibernian Society in New Zealand 1869-2000, Wellington, 2002.

94 Index Book Belonging to Father Garin, DNM 2/26, SMPA.

95 Nelson Examiner, 1 September 1858, 12 January 1859; Colonist, 17 February 1860, 20 November, 11 December 1863, 12 January 1864.

96 Colonist, 16 July 1858; Garin to Numa Garin, 17 August 1859, 23 June 1870, Epistolae (New Zealand), Z 208, APM.

97 Poupinel to Maîtrepierre, 3 April 1858, Historical Documents, HD 6, folio 153, MAW.

98 Nelson Evening Mail, 6 January 1883.

99 Nelson Examiner, 20 November 1852.

100 Nelson Evening Mail, 8 January 1883.

101 Fraser, Castles of Gold, p.156.

102 James Belich, Making Peoples: a History of the New Zealanders: from Polynesian Settlement to the End of the Nineteenth Century, London, 1996, p.416.

103 Nikos Papastergiadis, The Turbulence of Migration: Globalization, Deterritorialization, and Hybridity, Cambridge, 2000, p.196. 
Journal of New Zealand Studies 